\title{
ORAÇÃO DE PARANINFO
}

Pronunciada na solenidade da colaçáo de grau dos Licenciandos de 1956 da Faculdade de Filosofia da Univ. do Paraná.

\section{Prof. Albano Woiski}

\section{"Quid nobilius quam erudire iuventutem?" \\ - Que há de mais nobre que educar a juventude? -}

Nesta noite já memorável, na qual sentimentos se entremesclam com emoções, viestes emprestar o brilho da vossa presença à cerimônia da investidura de mais uma plêiade de educadores brasileiros, os quais julgam não terem desmerecido da grande honra de pertencerem desde agora à milícia dos defensores da civilização cristã em terras brasileiras.

Durante anos, êles acalentaram no fogo sagrado do entusiasmo e da fé, um ideal, e por êle se cansaram em árduos labôres.

Hoje, nesta solenidade, cujas origens se perdem nas sombras remotas das aulas-magnas medievais, êles vieram colher os louros da vitória em meio às a egrias de suas famílias, da cidade e da Faculdade.

Contemplai-os.

Diante do vastíssimo horizonte das suas mais férvidas aspirações sentem-se êles invadidos de angústia idêntica à que avassala a alma do artista que deseja em vãs tentativas perpetuar na dureza fria do mármore os movimentos aligeros da vida estuante.

Não podendo exprimir com os lábios tudo quanto vai em suas almas, sòmente encontram fôrças para, ao ritmo contente de seus corações, murmurarem silenciosamente preces de agradecimentos por verem concretizado seu mais querido querer.

Diante da pequenez da sua voz, insuficiente para cantar a sinfonia mirifica que eclode transbordante de seu íntimo, solicitam êles, vislumbreis, em vossos corações generosos, o simbo- 
lismo que envolve o desenrolar desta cerimônia, enquanto êles, em suas memórias vão tentando refolhear ve'ozmente as páginas passadas do livro da existência, para, taumatùrgicamente, fazer ressurgir o tempo que se escoou nas frágeis asas das horas que não mais voltarão.

Adivinhastes, senhores! Estão êles ansiosos por deixar esta Escola onde, quiçá, passaram os momentos mais emocionantes da sua inquieta e insatisfeita juventude.

A mocidade é energia insopitável; é fôrça irresistível; é uma divina impaciência. E êstes moços e estas jovens, vós o sabeis, sentem ânsias de voar até o infinito, de cavalgar o Universo, de brincar com as estrêlas, de mexer com o eixo da terra, de conquistar novos e mais esplêndidos triunfos para a causa da Educação. Sentem êles ímpetos incoercíveis de lutar pela intangibilidade dos sagrados principios que regem a Pedagogia. Mal podem êles refrear o desejo ardente de combater sem tréguas contra os profanadores da moral e do ensino. Desejam a todo o custo empunhar a pena cintilante do saber contra a fôrça obscura e destrutora da ignorância e do êrro. Querem alçar a sua voz esciarecida para levar ensinamento aos necessitados e orientar os marginais.

Meus afilhados!...

Aqui me tendes, atendendo ao vosso chamado. Se grande foi a honra da escolha, maior é a responsabilidade que me impusestes, pois o paraninfo deve ser como um oráculo. Por êle deve falar a voz da experiência; por êle deve abrir-se o caminho de uma nova vida; por êle deve descortinar-se o horizonte de um mundo desconhecido. Tendo percorrido, em longa e áspera caminhada a estrada que ides percorrer, a êle compete indicar-vos os perigos a evitar, os desvios a tomar, o rumo a seguir.

Há dez anos, como vós, eu deixava em meio de alegrias e bons augúrios, a querida Faculdade de Filosofia. Eu mal sabia, ao transpor os umbrais para a realidade, o rude caminho que teria que percorrer. Neste instante, eu volto a êsse tempo da minha vida e revejo professôres e colegas, e torno a ouvir lições que limaram as arestas da minha inteligência e da minha vontade.

Versado nas lições do tempo, nulo entre os grandes da inte- 
ligência, mas grande entre os experimentados na fraqueza humana, o vosso paraninfo aqui veio para fechar por momentos o livro da ciência e folhar convosco o livro da experiência.

Dêste cenáculo de estudo e pesquisas, forçoso é que partais para o deslumbramento do mundo onde a messe é enorme, árduo o trabalho e os resultados são parcos.

No entrebater sugestivo das emoções desta hora, a um só tempo temerosos e audaciosos, apresentais-vos ao mundo quais neófitos de uma vida nova, tendo no insondável do futuro a esperança por farol, a fé por âncora e a caridade cristã como pôrto.

Se difícil e fadigoso foi o caminho até aqui percorrido, certamente, na aridez da vossa ignorância dos problemas educacionais da hora presente, cresceram e medraram em labôres fecundos, verdes e promissores, os vossos conhecimentos da Pedagogia Moderna bem como a Técnica da sua aplicação, o que na verdade vos deve alentar e tranqüilizar, perante as grandes responsabilidades que vos aguardam $e$ as dificuldades que deveis enfrentar ao término desta festa.

No transcorrer daqueles quatro anos de Faculdade, aprendestes de vossos mestres que, se a Pedagogia quiser reinvindicar para si o título de ciência da educação, não pode evidentemente ser constituída por um amontoado de noções incoordenadas, por compilação de princípios, por amálgama de conselhos, como se fôsse um receituário, cuja única unidade aparente fôsse o livro que os contém ou a pessoa que os emite.

Aprendestes que, se a Pedagogia é uma ciência, o magistério bem compreendido e praticado é a um só tempo arte, política, ética, serviço social dos mais relevantes e alta filosofia de valores humanos e divinos.

O magistério, como arte, possui, é certo, as suas normas, mas estas, como tôdas as normas artísticas, fogem do fixo, do acabado, do determinismo estratificante. Ficam, por isso, as leis didáticas entregues à inesgotável aptidão criadora do professor, uma vez que a arte da educação descansa primordialmente sôbre a primorosa dignidade da matéria confiada às mãos do educador - a personalidade humana.

Na realidade, a educação não é verniz para camuflagens po- 
lítico-sociais, mas é um processo imanente que se confunde com a própria vida humana, pois em seu sentido pleno, forma o homem de seu país e de seu tempo, assegurando-lhe firmes e amplas conexōes com o universal. Educar é preparar homens que saibam viver como homens e não como coisas, como massa ou como máquinas; a educação é vigorosa fôrça de aperfeiçoamento humano. Deve a educação realizar bons pensamentos, boas palavras e boas ações. Deve dar ao corpo e à alma tôda a perfeição de que o homem é suscetível. Deve conduzir à virtude. Deve conter e dirigir os movimentos da alma de modo que as realizações humanas sejam dignas de um ser racional. Deve formar a juventude para as letras, artes e virtudes. Deve ser uma influência consciente e ref etida exercida sôbre o homem para formá-lo completamente. A educação, afirmou Montaigne, é a arte de formar homens, não especialistas.

Durante aquêles quatro anos de Faculdade, compreendestes que o magistério como política, deve necessàriamente ser uma disciplina constante da liberdade dentro da ordem, donde resulta que, em meio aos dolorosos conflitos, cada dia tornados mais dramáticos entre o mundo real e o mundo das idéias, entre a autoridade e a liberdade, entre o indivíduo e o meio, entre a pessoa e - Estado, não pode o professor moderno ser como fôlha sêca que os ventos varrem ou como testemunha muda dos acontecimentos que abalam a estrutura da sociedade, da escola, da família. Pelo contrário, mercê das circunstâncias, cabe ao professor de nossos dias, do alto da sua cátedra, ou da humildade da sua mesa de estudos, desencadear as rajadas da tempestade, como também a êle compete dominar as tormentas que abalam as consciências, quer como autoridade docente, quer como defensor da verdade, quer como acusador do êrro, profligando estrênuamente pela vitória do bem sôbre o mal, da luz sôbre as trevas, da sabedoria sôbre a ignorância, da virtude sôbre o vício.

Por isso, foi a vós ensinado que Escola não é fábrica de diplomas e que a arte de educar não é simples técnica de preparar alunos para serem bem sucedidos em provas, concursos e exames. Não é, nem pode ser a Didática uma improvisação de processos, rotina de preleçōes apressadas e mal alinhavadas pela memória, 
justificadas pela vertigem do século, pelas necessidades econômicas da época ou pelas exigências governamentais.

No decorrer daqueles quatro anos de Faculdade, aprendestes que o magistério como ética é um contínuo exercitar de virtudes morais, cabendo ao professor moderno fazer da sua carreira a mais nobre das missões ou a mais vil das profissões, uma vez que o magistério, tendo muito de paternidade, rea iza-se dentro de uma ordem geral de fatôres, em cuja órbita gravitam, se entrecruzam degladiando-se outros valores extrínsecos à função de educar, porém com ela concomitantes.

Por essa razāo, logo o sentireis, o magistério não é caminho plano e fácil. Não é e nem pode ser considerado como a profissão dos fracassados em outras profissões. O magistério está, como tudo que é humano, banhado de lágrimas e de alegrias, está entretecido de sofrimentos e de exaltações, está formado de amarguras e de esperanças, de desfalecimentos e de sempre renovadas ilusões, de tormentos e de delícias, já que, na humana condição, nunca nos é dado perceber em que medida uma vitória significa o atingir da meta desejada ou aperiás ó reinício de lutas e sacrifícios.

E' pelo amor ao magistério e às coisas do magistério que deveis ingressar na vida magisterial. $O$ amor à profissão de ensinar que é também missão nobre e sublime, que elegestes como a vossa, que exige da vossa parte saber e generosidade, energia e devotamento e sobretudo humanidade - eis a condição iniludível de êxito no magistério. Na verdade é o amor que vem transformando o ofício humilde em arte, o trabalho em criação, a tenacidade em heroísmo, a fé em martírio, o prazer em estesia, a idéia em dogma, a vergonha em sacrifício, a vida em poesia e o magistério em dedicação. Amai o magistério e fareis o milagre de dedicar vossa vida aos ignorantes, aos débeis, aos marginais, aos esquecidos, aos pequeninos, ao trabalho de ma'horar o mundo.

Nesses quatro anos de vida acadêmica, ficastes sabendo que, com o atingir da própria dignidade humana, o magistério é serviço social dos mais elevados, transformando-se cada professor em inspirador e realizador do "social welfare", uma vez que assistimos a um movimento educacional duma amplitude extraordinária, 
que é demasiado poderoso para ser moda passageira. O que se exprime correntemente pelas expressões "escola ativa, escola nova, educação dirigida, educação progressiva, escola de projetos, escola para a vida", designa, duma forma global, êste movimento renovador o qual reflete uma nova filosofia de valores cujo início está situado no interêsse, tanto individual como da comunidade. Estabelecer uma correspondência mais íntima e inteligente possivel entre o aluno e a vida social — tal é a missão da educação moderna.

Por essa razão, cada professor moderno torna-se um soldado aguerrido na luta contra os erros sociais que desajustam os individuos, bem como contra os erros individuais que dissolvem a sociedade.

Nestes quatro anos de Faculdade, compreendestes acima de tudo que o magistério é Filosofia das mais altas, em cujas ondas caprichosas se debatem os magnos prob:emas da sobrevivência dos valores humanos. A Pedagogia nada é, se ela não quiser ser uma metafísica incarnada, se não quiser repousar, em última análise, numa concepção da vida humana. E esta concepção está sempre relacionada com idéias possuídas da natureza protunaa do homem, sua origem e seu destino. Com isto afirmamos haver ao lado de uma Pedagogia Positiva, fundamentada na experiência direta, na natureza concreta e momentânea do educando, uma Pedagogia Perenis, racional e geral, fruto das concepções filosóficas, morais. religiosas, políticas sôbre o Homem e sôbre os valores humanos postos em jôgo na educação.

Por essa razão, a Pedagogia deve partir de uma determinação ontológica, apoiar-se numa justificaçāo ética e realizar-se por técnicas que comportem ação pelo interior e pelo exterior, espraiando-se na organização psicológica, pedagógica, administrativa e juridica da educação.

Daí resulta que, como homem, pcde o professor ter a fé que a sua consciência lhe indicar, mas na condição de Fiiósofo da educação deve êle ter segurança de princípios, e na condição de Técnico da educaçāo deve possuir confiança nos processos, para que não aconteça que, por sua ação, contribua para fins que não são talvez os que êle aprova; um educador moderno deve fazer 
sempre a distinção entre sistema pedagógico e fatos pedagógicos: pela razão muito simples de que Pedagogia é ação premeditada, é orientação escolhida, é organização e não improvisação, cópia ou simples experimentação.

Durante aquêles quatro anos de estudo meditado, ficastes conhecendo que, conquanto a Educação seja o imperativo mais exigente da Humanidade, não é ela valor absoluto, não é fim em si própria, mas é meio excelente para o atingir da perfeição, da santidade, cuja auréola faz rebrilhar a luz sacrossanta da Verdade, no complexo harmonioso de tôdas as virtudes cristãs.

Por isso não vos iludais com o saber que adquiristes e desde agora, com coragem humilde, proclamai que o que sabeis é pouco diante do que deveis saber. A profundidade do conteúdo da Pedagogia nos mostra a cada passo que há muito por descobrir no microcosmo, não bastando contemporizar com a dúvida, pactuar com a negligência ou negligenciar com o êrro. Os erros do médico, a terra os encobre; os êrros do advogado, a sociedade os esquece, mas os êrros do educador, qual epidemia, se transmitem através das gerações.

Educar é orientar. Na qualidade de orientador de homens, compete ao professor viver com o espírito sempre voltado ao estudo, não abandonando por um momento sequer o campo da pesquisa educacional. Como tôdas as artes, o magistério se adquire com sacrifício e na exigência de um permanente aprendizado que é a própria vida, pelo que mais vos valerá a modéstia de recorrerdes aos livros e aos mestres, que a ignorância enfatua. da pelo sofisma enganoso. E' vosso dever engrandecer a Pedagogia, enriquecendo-a com um idealismo cristão sadio e com um trabalho metódico e perseverante, pois jurastes, tendo em mira os princípios da honestidade, envidar todos os vossos esforços para que a Educação se realize, e tomando os bons princípios como guias, protestastes so'enemente nunca vos afastardes da causa da Humanidade!. . .

Neste século de racionalismo exaltado e de agnosticismo confesso, procura-se, na Pedagogia Moderna, arautos e modelos em todos os países, para dá-los aos professôres, esquecendo-se propositalmente que o único modêlo digno de ser imitado por 
pミdagogos é o Cristo da Galiléia que, afagando as cabecinhas das crianças, afirmava que é delas o reino dos céus, e anatematizava os que as escandalizassem; o Cristo que disse se desse a César o que a César pertencia; o Cristo que, com suas respostas de vida e de perdão, confundiu os fariseus $\epsilon$ os doutores da lei.

E' preciso que o professor moderno, imbuido de tantas teorias e de tantas técnicas escolares, não deixe de se modelar pelo Divino Rabi, o único, cujas palavras e cujos ensinamentos refletem direção, verdade e vida!. ..

Caros afilhados!...

Eis-vos chegados ao ponto em que, no alvorôço dos que acabando de vencer juntos a porfia, misturando atrope adamente num misto de vaidade explicável suas emoçōes, esquecem-se por completo que se vão separar talvez para sempre.

Porém, se forçoso é que vos separeis de vossos colegas e da nossa Faculdade de Filosofia, mostrai que $c$ gênio do prolóquio quando afirma "longe dos olhos, longe do coração" vai cheio de malícia, de epigrama, de engenho, mas vazio de ciência, de jusrica e de filosofia.

Apesar de separados pela distância, continuai unidos pelo espírito magisterial, pois se de um lado o magistério como arte não pode ser dogmático, como arte possui um estilo que não é unidade mas diversidade em sua forma expressional.

Desconheceis, é verdade, a posição que a Divina Providência vos reservou nessa nobre profissão que abraçastes com $o$ ardor dos que sentem o coração incontaminado, dos que alimentam a alma com luzeiros de esperança, dos que almejam atrelar seu carro às estrelas.

Porém, qualquer que seja a posição que ocupeis, jamais vos esqueçais de antes e acima de tudo professar vossa crença na educação como fôrça revigoradora de energias humanas para o bem, para a virtude, para o céu. Quer como políticos, defendendo da tribuna parlamentar a causa da educação; quer como administradores colocando o vosso saber a serviço da função educacional; quer como mestres exercendo a mais excelsa das missões, meditando a Pedagogia e transmitindo luzes às novas gerações, quer como jornalistas, levando a educação, qual alimento 
cotidiano, à bôca sempre faminta do povo, - jamais olvideis que a tarefa de um homem se torna leve, se o seu coração está sempre leve, se a sua consciência está sempre impa, se as suas mãos estão impolutas. Lembrai-vos que o que importa não é o lugar que ocupamos na sociedade e sim o modo como o ocupamos. Mede-se assim o valor de um professor mais pelo que êle pratica do que pelo que êle sabe. Na nossa profissão os títulos vêm atrás; à frente devem vir os atos.

Com ser arte e profissão, o magistério não deixa de ser também coração, altruísmo dos mais elevados, onde as confidências muita vez refletem corações infantis e almas juvenis angustiados, consciências adolescentes pesadas, ressumbrando interêsses talvez inconfessáveis, sob forma de problemas educacionais abscônditos, mas tão reais como a própria vida. Nos tempos que correm, compete ao professor colocar-se inúmeras vêzes no lugar do pai, transformando de certo modo a vida humana em 'ógica, reduzindo a problemática humana à lúcida exposição, as questões educacionais em claro esquema mental, para resolução de casos de consciência.

Por êste motivo, o pensar e o agir do professor atual não devem distanciar muito do pensar e do agir do sacerdote, no qual se devem casar inteligência, intuição, sensibilidade e atividade, para que os regulamentos e as ordens não sejam duros e frios como o granito, mas emanem eflúvios de compreensão bondosa. Eis por que motivo deveis considerar o magistério também como um culto que subentende acima de tudo finalidade superior de vistas e dedicação aos educandos. Mais pela bondade e auxilio despreendido, mais pelo confôrto de oportuno conselho, mais pelo contágio desencadeante do vosso bom exemplo, mais pela vossa ação didática esclarecida, que pelas rutilâncias altissonantes de retórica egoísta, que pelas vossas atitudes formalistas, convencereis as inteligências adolescentes, ganhareis as vontades juvenis mais recalcitrantes e opereis o milagre humano da educação.

Ao magistério sempre coube a tarefa gloriosa de trazer a mensagem de novas esperanças ao mundo conturbado. Nāo desconheceis a crueza da luta que vos aguarda, os sacrifícios que vos serão exigidos, porque nesta Faculdade recebestes o preparo 
conveniente para a vossa missão de apóstolos do bem. O conhecimento da causa por que ides lutar, em vez de trazer-vos o desânimo dos pusilânimes, vos agigante a coragem, inda que saibais que por esforços mil um só seja o resuitado.

Que a vossa palavra de professôres, sempre se eletrize, trema, lampeje, atroe e fulmine o êrro, a injustiça, o vício, a desordem. Que a vossa ação magisterial, qual faúlha do vosso entusiasmo, esfuzile centelhas, que ao atravessarem os limites da cátedra, da tribuna, da imprensa, da sala de aula, dos laboratórios de pesquisas, das bibliotecas, faça resplandecer o poder de Deus, - valor da pessoa humana, faça rebrilhar a Verdade, faça rutilar a Justiça e assegure a Paz!

Não vos acobarde a multitude de tropeços e não vos intimide o fracasso de um dia. Se nós, professôres, quisermos, o mundo será melhor!. . .

Com as bênçãos de Deus, com o ânimo alevantado, com o espirito vigoroso e com a vontade decidida, marchai sob o pálio da Ciência Pedagógica, abroquelados pelo escudo da prática docente esclarecida, em defesa da Escola, em defesa da Família, em defesa da Sociedade, em defesa da Pátria e em defesa de Deus!... 